\title{
ЛІТЕРАТУРНЕ ДЖЕРЕЛОЗНАВСТВО
}

DOI: $10.31475 /$ fil.dys.2018.08.20

\section{Докія Гуменна. Щоденник Зошит 23}

\section{V.1949 p.}

Я повинна багато чого обдумати і вияснити, як далі. Визначити свою несхибну лінію, бо в цій темноті (такій, як уві сні перед виїздом 3 Києва 3 хрестом Святої Варвари) тільки це почуття виведе. Більше ніякої поради, ніякі Люби, ніякі доброзичливці та доброчинці.

Так виглядає, що я не вилізу з табору нікуди. Тут доживатиму віка, в богадільні. Все життя я надіялася, що як усно не вивезу, то писано. А тепер бачу ціну свого писання, не вивозить воно, не дає забезпечення (як дає, то комусь, е такі, що купують мою книжку, посилають, їм за це - пачку). Ніхто не потребуе мене виписати. Ніякої роботи, крім хатньої прислуги, для мене нема. Одним словом, своїм, українцям, не потрібна. Зміст мого життя - порожній звук. Недаремно вибута я з небуття. Це немиле мені життя не тільки мені не потрібно - нікому. Одначе, що ж мені з собою робити? Коли я прийшла до такого краху, то що щось маю зробити. Перегляд усього, що діялося зі мною, та оцінка.

Усе, усе, весь перегляд, до чого не торкнусь, каже мені - я загибаю. Повільно, але загибаю. Наче організоване кругом мене кільце удава, воно здавлюе мене й матеріяльними, й моральними кліщами. Моральними - загальний остракізм. (Вже навіть Віктор Платонович (Петров. - T. Ш.) не відписав). Із МУРу так викинута невідомими силами, що я й сама там не хочу бути. Організовано, що друку я не бачу. Всіх, навіть В.Коваля, навіть Маляра, повипускали, а я грибом сиджу на своїй валізці. Це саме, що й у Киеві. Матеріальних злиднів кільце все більше і більше стискається і цей хижацький цинізм моїх грабіжників. Я 3 інтересом чекала, чи пропустить мене комісія. Передбачала, що й тут проти мене пущено в дію машину. Той «сіейсі» або советський агент, або бездарний «сіейсі», якщо вже це він мене не допустив. Весь мій шлях - біди й затиску, - а цей питає: «А з чого жила?» Отож то, що все життя - голодна та люмпен.

Тепер я й новим панам не до смаку. А все те робиться елегантно, в рукавичках, навіть не дізнаєшся справжньої причини. Вони ж і до Лондону не посилали, хіба за два тижні може прийти відповідь? Отже, кільце навколо мене стискається, вони, корнійчуки, хотять таки доїхати мене, довести, що і в них я не могла розвернутися, та й тут не вдасться. Я думаю, що це і е скрита пружина у невипуску 4-ої книги ДЧШ 
(йдеться про роман «Діти Чумацького Шляху». - Т.Ш.). Мене вони хотять затягти у пастку. Треба підготуватися гідно, як перед смертю, а може й перед смертю.

3 цього всього безрадісного, темної ночі й болота, найважливіше, що праця моя, жертви мої й зусилля - даремні. Все - в дим, у небуття. Якби я не згубила цілі, то всі ощі неприемності мене мало обходили б. А ціль я згубила, як зрозуміла безправність і нікому не потрібну свою саможертву. Я бачу все обернене до мене спиною. Так багато великих $\mathrm{i}$ малих, гострих і болючих кривд, що мушу знайти спосіб на те все відреагувати і видужати. Метод життя знайти. Чи свідомо прийняти ролю саможертви? I тоді всі грабіжі, образи, моральні й матеріяльні голки та відпихання від великого життя - стануть неразючі, а - так треба. Я віддала все, що мала, і за це дістала нагороду з тернів?

Але кому? Кому ця жертва? Хижакові? Зміст релігії у тому саме, що жертва і жертя - все докупи. А тут ти для когось увесь час жертя. То хижакові?

Скільки я не думаю, не можу змиритися, знайти рівновагу. В природі є це безперервне жертя, але є весь час і дифузія, вирівняння. На мої жертви щось ніякої компенсації нема. Раніш було у вигляді екстазів, тепер дух мій все сумрачніший і сумрачніший. Три рази в день над собою плачу і питаю себе: Чого? Все гаразд, все добре. Ти хочеш звільнитися із в'язниці життя, - це прийде. I всі ощі лиха - тільки поміч до твого найбільшого бажання. Веселого Духу! Безжурності. Спокою душі! Хоч нічого нема, що не стоїть спиною до тебе, ...але у інших безмірне горе, втрати, а ти тільки пригнічений дух маєш... Все гаразд, все іде якслід. Не трагедія, що не випускають до країн, що зуби вилітають, що нема їжі, - все те дрібниці. Ну, заскочать тут, ну, повісять, ну, повезуть у вагону, ну, муки... Колись же треба їх перенести, як хочеш із темниці життя вирватися. Дбай завершити свій витвір, убезпечити, поки є час. Не для їхнього жертя, а для себе, як свою внутрішню потребу.

Тож попалася мені юнацька книжечка бенгальського письменника Дган Гопаль Мукерджі, в якому видно виразні сліди буддійської релігії. В ній усе побудовано на навіянні й самонавіянні. Вона могла б бути моєю. Я мушу з неї дещо виписати сюди і роздуматися. Тепер я бачу, що родичі мої не східні лінощі, а ось це саме роздумування. Подібне на гіпноз. Останніми часами я багато присвячую думок релігії. Попалась "Арка», тоді - Великдень, старість і мої думки. Я думаю не так, як Віктор Петров, ембріон релігії -не культ предків, а культ їжі. Якось треба зібратися і систематизувати ці думки.

4.V.49 p. 
Я мушу докопатися, чому в мене таке розчарування з появою трьох книжок і «відомістю». Це нічого мені не дало. Порожнечу й почуття ограбованості, зжертої. I де вихід? Не дати нікому більш? А не дати - не треба писати. А не писати не можу. То що?

Шерех - це Полторацкій. Таж сама зарозумілість, те ж варяжство, те ж «з вищої культури снізошел» і тут скрізь підкреслюе свою вищість. Теж українізувався. Теж знає мови, бо з інтелігентної сім’ї (мати німка-вчителька чи що). Те ж чуже почуття до українського та деклямація про українське.

Як тоді Полторацький звисока ставився! Ми були на одному курсі. Я була в його очах щось дуже мізерне, сіреньке, сільське. Навіть не набереться синонімів утвердження моєї непрезентабельності. I я його, це відчуваючи, ненавиділа. Здається, вже й цього.

\section{VI.49 p.}

А ця теза справді дуже допомагає. Як я нікому непотрібна, то нема на кого сердитися. I це добре, що я все собі усталила, що завершила свій шлях «Скаргою» і «Киевом». Трохи сумно, що всі вже виїжджають, але знову ж, - хіба як вони були тут, то чи не однаково, що нема їх тепер? Про МУР думаю: допустили мене, а я уявила собі, що я серед рівних. Мені й показали моє місце. 3 цього висновок, що й «виходити» 3 нього не треба, лише здивуватися, коли хтось мене за МУРівську одиницю визнає.

Отже: де я не буду - серед муринів, американців, австралійців скрізь я буду серед людей, ні більш, ні менш, як тепер серед українців. А що дано мені думати та говорити по-українському, - то сліпа доля народження. Нема мені з того нічого. Це мій інструмент, тільки.

Але як воно достоменно повторилося тепер те, що було десять років тому. То чого ще ждати і надіятися?

I та безодня. Я ж, як виїжджала, то саме так, що вже кінець. Я тільки цікавилася, що по другім кінці. Дірка від бублика.

\section{VII.49 p.}

В мене все життя було почуття, що головний мій козир - попереду ще. Тепер це почуття зникае. Тому мізантропія.

Не знаю, як триматися з П. Горбанем. Це мені вперше. Бо з тим товаришем його, то ясно, як. А з цим - не хочу дуже на рівну вікову ногу ставати, бо буде смішно і мене осмішить, і не дуже до душі мені роля матрони. Ніяк не вступлю в ту ноту, як легко. А тут як раз хлопчина такий, що повинно бути легко , бо то - добрий товариш, і саме такого я не бачила, як мала 24 роки. Легкість ума, м'якість і тонкість вдачі, веселість душі. От ця пропущена можливість, цей незустрінутий товариш тепер може наводити мене на безліч думок - збоку, зверху. 
Усе життя була я в братських стосунках 3 найближчими мені душевною структурою товаришами. Світ того не розуміе i зразу приписує романний зв'язок. Жертвою таких висновків стала й дружба 3 Багряним. От! Навіть і приятелювання 3 чоловіками обертається якоюсь гримасою проти тебе. Навіть і просто сусідування. Ти служниця, бо миеш за сусіда-чоловіка підлогу, в випадку сусідування. Ти - жертва пліток у випадку приятелювання.

\section{Зошит 24}

\section{XI.49 p.}

Всі думки в одному напрямку. I нема з них виходу. Це тому, що я безсила змінити щось у обставинах. Терпляче чекати якоїсь зміни і час на приемне вжити? Яке? Як катують мене спогади про цю «Баварію» 3 Австрії і всі зв'язані з цим зневіри. Як жодної світлої прогалини нема. Тому, може не хочу нікому нічого писати.

\section{XI.49 p.}

Як я у лісі, то все чудово. Так усе й належить бути, весь світ мені батьківщина і я повна об'єднаності зі світом. Як я увечері, або ще перед сном, то неможливо, ані жодної хвилини. Весь комплекс зринає, вся невдача. I вона однакова - в «цім» світі і в «тім». Всі вони підряд кажуть, що я - примітив. Так казали Плужник, Любченко, Стебун, так дивилися на мене. Так каже Самчук, Шерех, Косач, за ними повторює Дивнич. Люба взялася протегувати звисока.

Цей Абраменко, все ж, цікавить мене. Ось починаю думати про якусь людину денно і ніччю. Скажи це кумасі якійсь, - зразу зрозуміє по-кумасиному, починаються недоречні жарти. А я переконалася, що мою думку приковуе складність і понадпересічність.

Так от Абраменко. Зовнішність орангутанга, довгі руки з ухваткою орангутанга, та ще й горб. Постать неприваблива до крайності. Але який певний себе! I я цікава - чому? Знань мае багато, астроном, математик. Може 18 годин щодня працювати. Ходить на забави i танщюе. Раптом береться за вибори й провадить їх від початку організащії до кінця. В розмові всебічний, докладний, логічний. В наукових працях такий самий, як і в житейських, за яку береться, коли береться. Не хапаеться за все, не кидаеться, кар'ери не робить, але як уже візметься, то сумлінно, добросовісно виконуе. Знае мови, видко самоуком, бо англійська слаба.

\section{XII.49 p.}

Дві ночі тому снилася мені рожева, дуже гарна, нова, невбирана нічия сукня, з довгими мережками. Подарована мені, від Майстер. Ціеї ж ночі я вбрана в білу довгу невбирану досі сукню 3 дуже гарного 
недоторканого шовку. Іду до якоїсь їдальні й швидко переходжу через простір, де літають клапті чорної сажі.

В їдальні повно людей, всі обідають. Я проходжу туди, де й учора сиділа, сідаю за стіл. Шість кусків білого хліба лежить, офіціянтка приносить збоку котлети. А передо мною хліб забирає, прибирає, мені не дадуть уже. То ж усі ще їдять! - Таке розпорядження, - вже не давати.

Я страшно розчарована, обурена, збентежена.

Що це? Прообраз майбутнього? Це так буде мені в Америці?

\section{XII.49 p.}

Крізь облудний туман компліментів типу Курінного чи Кривов'язи («Вас люблять», «ваш талант...») який все ж заколисуе, раптом уночі проріжеться блискавка невблаганних фактів. Сума їх - «мене затюкали». Знову, ще раз і ясно. 3 нових фрактів (а ті вже я пережила раніш і вони влягалися гіркістю на моїй психіці), з нових фактів, ЮД зовсім безцеремонно і безпардонно не відповів на мій лист. Це виглядає, як розрив. Півроку тому я, перераховуючи свої втрати, думала: «Ще є Дивнич і Парфанович. I всі». Тепер ні цього, ні цієї.

Найсвіжіший фракт. Ось учорашня газета «УВ», стаття Юрія Соловія (хто це?) «Український олімп 1941-48 рр.» Там цитата: «Такі твори наших письменників, як «День гніву», "Старший боярин», «Ост», «Без грунту», «Морітурі», цілком добре лежали б поруч із творами Гемінгвея, Жуан Джона, Кестлера та інших»...

От, що є оцінка. От, коли правда, а не компліменти. Недаром ніхто 3 них не висловився про мою роботу, вона не варта уваги, бо не література це. Замовчання це такої ж ваги оцінка. I от на «Ост» так само етикетка: «Видано у співпраці з видавничою комісіею МУРу». Як і на всіх солідних виданнях - «Без грунту» та інших. МУР же від моеї роботи «умив руки», то - нижче рівня його мистецтва.

Недаром Самчук поширював видуману, не знати з яких джерел, поголоску, що я взагалі нічого не читаю і не хочу читати.

Отака дорога моя. Висновок ясний, що існуе прірва між мною і ще одним літературним процесом. А без них - нема повітря. Від них отруйне. Ні з ними, ні без них. Не вихід сказати: «Більш не буду нічого писати», - i десь, у якомусь Трой мати «кімнатку на тихій вулиці» та строчити на електричній машинці і їсти консерви. Тут так само, як і 3 нерозв'язаним: не хочеться ні жити, ні вмирати й нема третього виходу. Третій може бути - божевілля. Але воно мене ще, покищо, не береться. Тут: «ні писати, ні не писати». Жити і не писати це капітуляція. Я не писати, то единий вихід - знищити себе. 
Це і є той момент, який мерещився мені в 16 років (через 30 років!): хоч навкарачки лізти, хоч померти в досяганні, не досягнувши порога мети, - а лізти, хоч 3 останніх сил, 3 покривавленими коліньми й руками, з останнім віддихом. То було сильне безсмертне бажання, чи воно вже вмерло?

$\mathrm{Hi}$, не вмерло, але я не знаю, як його втілити. Як знайти атмосферу, чим дихати? Без них - нема, з ними - не хочу. Не хочу в ті ролі, яку вони для мене мають. Як я добиваюсь іншої - вони дають по руках: не лізь! Вони допускають тебе в ролі протегованої слабости, бач, навіть Люба засвоїла собі цей тон протегування.

Як? Десь закопатися в містечку чи фрармі і з тієї позищії, що «я вже вмерла і з того світу дивлюся на цей світ?» Це виглядатиме як доказ моєї недолугости, як вони всі й твердять і як не є. Творити інший гурт, Галина Журба, Чапленко, Парфанович? Інший гурт - це нездорова путь. Самій? Це зробити собі світ, але для світу - недолугість.

Мені підходить тільки роля «збунтованого Янгола». I думаю часом, що він мав ращію, повставши проти Бога. Тільки збунтований Люцифер, Демон (у святому письмі) це речник зла, а я проти зла повстаю. Отого самого, яким нагородив нас Бог своїм немудрим законом вчиняти другому зло для ствердження себе. Такий закон дав він істоті, i всякі релігії, - це прикрити, злагіднити цей закон.

\section{XII.49 p.}

Пирогов про «Ост»: - «Кулінарная книга».

Справді, в цій книзі персонажі тільки їдять і п’ють. Дуже важливо, як розсадити, як стіл виглядає, приготовлений для гостей. В хуторі $є$ піяніно! Покривала на меблях і картинах. Приїхала з Києва жінка одного сина, художника i $\dddot{1}$ звуть: «Пані Катерина!» Селяни висловлюються на польський лад: «Но!» Або кажуть «казетка». Невдала й убога імітація соковитої народної мови. Нема так, як казав до Ганни Давидівни Шурка: «Це пальто вам підходить і по кольору, і по упитанності». В хуторі $е$ «пивниця». Це - на Київщині! Дванадцятилітній гімназист зарозуміло 3 апломбом називае себе письменником... а ми ж то знаємо, скільки справжній письменник напращюеться, щоб дозволити собі таку назву. Це, хіба, початківець так себе величає. Гетьмана вже прогнали, а панські маєтки ще тільки думають розбирати!

$\mathrm{Hi}$, нема в цій книжці духу часу, а е самчуківське міщанство «з порцеляновими карафками», празько-польськими етикетами (i ми, мовляв, не ликом житі, знаємо, як між людьми поводитися - ідея спеціяльно Самчукова). 
I ще дивна картина сучасності. Як Корнійчука, так і Самчука всі в розмові невисоко цінять, кажуть - нудно, нічого не додає, старо, переспів «Волині», - багато кажуть. Але в пресі з'являеться лише хвальба i оцінки: «найвище досягнення». Там боялися образити партійні кола, ЦК компартії, а тут, знову, вузьке коло, зв'язане знайомством. Нема незалежної преси. Ніколи їі нема? Чи страшно образити «маститого» маестро Самчука? Чи критика продажна, коньюктурна?

Ага, ще! «Революція не ми, - каже Андрій. - Ми їі використовуемо». То для України чи для куркулів і революції не було? ? ?

\section{XII.49 p.}

Зранку не дає спокою цей сон. Прокинулась удосвіта від нього. Почуття гидливості не кидає. М'ясо... Третій день підряд - м'ясо. Цим разом із страшними великими й малими червами. Я бачу, показую комусь (близькій жінщі), вона швидко його десь ховає. М'ясо це треба роздавати.

\section{XII.49 p.}

Хто належить до богів, - немае права скаржитися на житейські недогоди, бо в богів нема й потреб житейських. От так то!

\section{XII.49 p.}

Тільки невгасимий вогник у душі. Це все, що маю. Гнана, невизнана, без всього, що мають інші. Збойкотована. Все життя в холоді. Але я можу гратися. 3 цим і пройшла через життьову дорогу.

Трохи (ні, не трохи) болить ще й Д. відвернення. Але це законно. Щодня жду вістки від нього і нема. Що ж, так і буде. Тепер уже я зовсім сама. Так, як я собі приготувала. Тільки гідно треба свою божу дорогу дійти. Боги не мають права скаржитися.

Отже, я була минулого року на піддашші, великомученищею. Навіть розп'ятою за людей. За рік я стала безтілесним парнаським небомешканцем. Мені не треба ні дров, ні масла, ні обідати. Все менше і менше потреб, навіть менше, ніж вділяе IPO, бо ж картоплю й інші «калорії» я віддаю курчатам.

Але богиня мерзне!

\section{XII.49 p.}

А до чого цей сон? Велика картопля, чиста, гарна. Я їі чищу, біла, без плям. А розрізую - в середині чорне дупло і нічого нема спожити.

Ще: ми, - наче я і Людмила Ткаченко, - їдемо до якогось фрранцуза, в якийсь журнал, найматися. Він нас пробуе, питає і... відмовляе.

Ще: якесь будівництво, я кудись приїхала, але ще треба знайти Юрка. Це - сім кілометрів і я йду. Дощ, болото, ніч. Спочатку було зрозуміло, куди йти, а потім зовсім пітьма. На будівництві виявляеться 
Гірняк, це тут вони всі, але Д. (очевидно, йдеться про Ю. Дивнича. Т.Ш.) не поспішає мене бачити. Гірняк сконстатував, що я е, і робив своє. Потім трохи вернувся... Але це все блідо й ніякого ентузіязму зустрічі.

Чого це такі безнадійні сни сняться? Це прообрази, може близького прийдешнього, а може й наступного періоду. Якась обмана i розчарування. Очаровуватися, правда, нема чим, бо навчила мене вже «Баварія». Але човпти якось треба і я бачу це без очарування.

Хотіла б якось ударити Людину. Якось в солодкій цукерці піднести їй правду про неї, не царя природи, а паразита. Все-все брехливе,

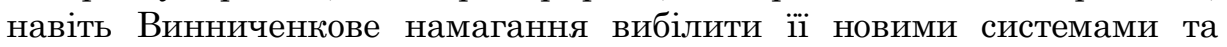
вірами в конкордизми.

Одним словом, останні години 49-го року в мене псуються катастрофічно і я близька до безнадійних ридань. Торік я працювала, чула, як зустрічали новий рік гульнею інші та загляділа пару ракет. Цього року... Плету відразу вже негарного шалика і думаю про оцей вузький овид довкола.

Думаю про те, що я була в трьох письменницьких організаціях і жодна не підійшла мені. Навпаки, кожна намагалася мене затовкти. Тепер я знаю, що ніяка спілка не варта пса, ні псового посліду.

Я трохи помиляюся, я ж була ще в «Плузі». Може то - найменше зло було.

Ще три ночі переночувати - і я назавжди їду з Пфорцгайму. Так я хочу. Хочу не вернутися, хоч би й не прийняли мене. Чи вдасться мені в Людвигсбургу зачепитися? Чи до Цуфенгаузену, уздріти Подоляка (Гр. Костюка. - T.Ш.). Здається, там уже нікого нема.

Якщо ж я таки опинюся в Нью-Йорку, я буду старатися відразу в окремий шлях ступити, щоб не дякувати вже нікому. Це, ясно, буде ніяка не література, але я не бачу розумного виправдання. Хто це той, до кого я б хотіла говорити, де вони?

\subsubsection{0 p.}

Останній вечір сама - до якого часу? Узавтра вже дома не ночую, а позавтрім до Людвігсбургу. Чи шкода 3 цим буттям розставатися? Справді це, як на Левашівській. Попереду мізерія міської самотности серед мільйонів і скрут поспіху та пресу над собою. Але що краще? Отак без жалю кидаю і без інтузіязму їду. Волочусь по світу. Не жду нічого і не хочу, бо як хотіти того, що не дається?

Тут - незакінчені хвости, але вони мертві. Це - четверта книга ДЧШ, «УВ» і словник... з Франції.

Цей день був монотонний і зовсім без подій, як не вважати сну. Якийсь у цивільно-військовому молодий хлопець ходить по квартирах, 
перевіряе все. Наче в Києві. Бачу його, як серйозно по-діловому офіційно честь віддае, входячи, й оглядає все.

Я йду додому, там мама, Льона, Ганя, Вітя, ще якась родина. Кілька газет хочу прибрати, зім'яла їх, але цей уже заходить. Глянув туди-сюди, говорить мало, я пробую щось сказати англійською, фрранцузькою мовою. Він перегортае книжки на етажерці, бере в руки археологію, а того, чого я не встигла прийняти, - не бачить. Потім українською мовою звертається, просить провести до другого будинку. Свій хлопець, українець.

\section{I.50 p.}

Будучи чесним і нехижаком, треба перейти на сіль і воду. А не на рослинні страви, як думають наївні вегетаріянці. Бо рослинні страви їсти - так само їсти живу істоту, нищити і мучить іншого, для того, щоб жила я. Сдині вода й сіль з того, що вживае людина для свого годування, нікого не кривдить, не кровопролиття. Чи можна за цим жити? За водою з малою приправою солі чи довго витримала б? I чи це не первісне харчування амеби, яка постала перша.

Bсе, що не глянеш, усе кричить: ти - хижак! Торба - з тваринної шкіри, - колись тварина страждала, як їі вбивали. Одежа - 3 вовни, а 3 рослинного волокна - трупи. Колись жило воно. Ліжко - з трупів дерев. Людина жере трупи, вдягаеться в трупи, ходить і спить на трупах. I мусить підпорядковано, покірно і далі чинити зло, хоч уже і усвідомила це.

\section{I.50 p.}

Вже кілька днів живу сном. Велике місто на висотах, що збігають вниз. Здається, над містом на великому просторі зорі якість через усе небо літають... Парки і ліси, пронизані рожевим промінням. I чомусь I.Коровицький весь час тут.

Це вже Людвігсбург.

\section{I.50 p.}

Хвалити Бога! Слава Богу! Це одне й те ж слово. - хва-ла, сла-ва. Так же й Слов'янське море звалося: Хвалиським морем. Хочеться простежити таємничі колишні уявлення, що створили сучасне поняття. За тотемним розумінням слово «слава-хвала» це ж і Бог. Казали просто: слава! Хвала! Як і в нас. Як щось добре, то - слава!

Я несподівано зустріла в американській літературі доісторичне світовідчування - як уявляли собі світ найперші люди. Цей письменник William Saroyan, а присвячуе свою книжку «Людська комедія» матері, вірменці Гасіоні Сароян. «Ми у всьому, все в нас. Птиця над головою, риба в морі - все це частинки життя, нашого життя. Кожна жива істота - частина життя кожного 3 нас. Багато 
речей, що не можуть рухатися, як ми, частина нас. Сонце - частина нас, земля, небо, зорі, ріки, океани. Все це - частина нас і ми прийшли сюди, щоб втішити його й дякувати Богові за це», - каже мати дітям. Також каже, що батько їх не вмер, а тільки його тіло. Він живе з нами, в дітях, молодший, дужчий, сильніший.

Це як раз так думали первісні філософи. А я от додумалася, що саме моє існування - злочинне, бо існуе завдяки злові другим існуванням. Я так уже відірвалася від цього всього, що е частиною мене і що все це - я. От саме так я хочу: щоб була я скрізь, а для того треба не існувати окремо.

Пару днів тому я наважилася думати, що релігія це - фральш людська, щоб прикрити нею людське хижацтво. Тепер я сказала б, що вона була чиста і правдива, поки люди почували себе так, як мати Сарояна. Але теперішні... Щось тут тепер нещире, самообман і заміна релігії обрядовістю. Масові вбивства свиней на фабриках - і для цього їх вирощування на фрермах. Інкубатори курей, курячі ферми і консерви в бляшанках з курей...

Та, власне, вся сучасна промисловість... Це - переробка наших рідних братів і сестер для нашого вжитку. Гітлер із своїм милом i рукавичками 3 людського тіла нічого нового не видумав, а довів до логічного кінця сотнетисячолітній процес розриву людини 3 Богом, культу его, я.

\section{II.50 p.}

Вчора я прочитала в газеті про близьку конференцію МУРу і ця замітка спонукає мене до остаточного розрахунку. 3 цим світом? Ніби так, бо мати оточення - моя потреба. I я від нього відмовляюся, отже і від цього світу. Подоляк, Костецький, Шерех, Багряний, Кошелівець... З ульмівським хам’йом (драбугами, жлобами) вже раз назавжди треба покінчити. То як бути?

Все одно, вони мене затюкали, виштовхали, зневажили. $\mathrm{Hi}$, до цього світу я вже не вернуся. Я вмерла для нього і він для мене вмер. Я почуваю, що вже після своєї смерти дивлюся на них.

Що ж це? Капітуляція? Страх? Зрада собі? Я ж казала, що хочу досягати.

Того, чого могла, я досягла. Тепер - або тріщати і зламатися, або витримати. Тільки вже без надії ні на яке оточення людське. Якщо зумію втриматися на якому обломку, то вже сама із книжковим світом. Для людей я - архаїзм. Правда, не вони мене робили тим, що $е$, і не їм відбирати від мене те, чого добилася. Але я для них, вони для мене - не існують. 
Треба подумати й про те, що от десь будуть збори, будуть вітати одне одного, радіти... А мене там не буде...

Що ж... I так, і так... я для них «якась там Галина Журба»...

I про те подумати, що в їхніх очах виглядатиме це крахом. В чиїх очах? Чиї очі можуть мене занепокоїти? Як я вже всім плачу тією самою монетою, що від них дістала. Я можу, хіба, на людину злий памфлет скласти, на цього самозадоволеного хижака, лищемірного, щось про реального просторіку. Оце ще може бути останній порятунок. Але як я усе писала без надії, так і це ще - то для кого і для чого?

Може я знайду радість у простій роботі?

\section{II.50 p.}

Моя постійна думка працюе, розвивае концепцію. Не все чомусь втілюеться в слова. Але вона $є$ і зовсім відмінна від усього - оточення, способу їх мислення, всіх фрілософрських систем. Та упорядкувати їі ще не можу. Все було щось у мене неясне, недодумане з 13-х років. Тепер уже додумане.

...Зовсім не жаль, не страшно, як тобі (мені) не попадає всього того, що іншим. Його мені не треба. Що менше, то краще...

...Щоб мати право просити щось у Бога, треба перейти на сіль i воду.

\section{II.50 p.}

Щастя - бути собою. Нi серед більших, ні серед менших, розумніших, дурніших, дітей, старих нема змоги - бути собою. Треба до них допасовуватися. Рідко коли - як ти. Нема. Тому - тільки сама я є 3 собою. I в оточенні, і в розмові з собою. А ще - не зважати на суд шерехіяди. I не боятися: як не так, як вони, костецько-полтави, хочуть, то й без цікавої атмосфери.

У них своя, а в мене своя. Яка не є. Це - я є собою. 3 своїми думками й уподобаннями-смаками. Без нікого, без їхньої слави i визнання. Мій світ. Який він - може примітивний, може вузький, може невисловлений - моє це діло. I як не буде навколо мене моєї атмосфери, хай без людей, - то біда мені. Отже, писати листи до себе. Це хіба не те саме, що до друзів, коли говориш з папером? Тому... Хай вони б'ються за гори зіпсованого в друкарнях паперу i за список друкованої нісенітниці. Я може більше знайду рівноваги в утомі від «клінування» підлоги.

Нащо було родитися, як треба (прийдеться) вмирати?

\section{II.50 p.}

Такі цікаві думки, - прокидалася чотири рази і шукаю виходу. Здається, я його знаходжу. В упертості. Я учора стала перед власною капітуляцією i це було найстрашніше 3 усіх моїх невдач. Сама, 
згубивши середовище, без місця в українській літературі. Що ж далі? питалася, - куди й по що? I от два дні оцих! Я в смішному вигляді, і думи про красня, який однаково схожий і на міжнародного гангстера, i на ніжного поета, і на дрібного таборового спекулянта, в елегантній одежі й з манерами аристократа. «Зубний біль у серці» і протест проти цього «порозуміння поглядами». Ефемера і різні повчальні науки 3 цього. I нема виходу.

Але вихід є. Вмирання і нове народження. Ніколи невмирання. Мета. Комета відірвалася від своеї сфери тяжіння. Скарга є. Тепер нова мета: вивчення чужої мови як своєї. Для цього треба йти в таке середовище. Ніяких псевдо-українщів, а вони тут, не вдома, всі такі. Зразу в іншу стихію. Без інстинкту самозбереження. I як що досягну, то щастя, а як ні, то друге щастя, що не скапітулювала, а згинула в досягненні. Чи потягне мене до потуг майстерності?

Оці думи про світ і його закони, не такі думи, як у всіх, чи причепурити формою? Може й ні. А перед ким я маю звіт складати? Я думаю - воно однаково нікому неінтересне і незрозуміле, мені одній запально цікаве. Я сама. Я буду собі свій світ творити. Щоб не скапітулювати, не зрадити себе, шістнадцятилітньої. Тоді мені дається роля спостерігача понад усіма інфузоріями, яка мені часто не дається. I можу вже бути сама. Перейти в вищу стадію.

Уночі я сама собі хотіла розказувати щось. Так, як би тому, хто зрозумів би й сприйняв вірно. Навіть не так, як Ганна Давидівна, хоч вона дуже близько стоїть до такої людини. Але все ж не та. Отже такій людині. Але то - треба зловити. Вже сьогодні не хочу.

Цієї ночі знов снився Віктор Платонович. Що він - є. Якась демонстрація, він співае, йде 3 іншими. Але сни такі неясні та заплутані. Вчора приснилося про Павликовську те, що я опівдні дістала від неї. Як ішла на пошту, о певна була, що цей лист дістану, i знала, що в тім листі написано.

\section{II.50 p.}

Бог чи Доля до мене невблаганні. Тільки, як я невгодна Богові чи Долі, чого було мене творити, давати мисль, нащо тримати мене в порожнечі?

Велика порожнеча утворюеться навколо, гнітить мене і давить. Я вже відкидаю поняття несправедливості (бо можна мені заперечити, що є інше мені дане), але мене розстрілюе безглуздість. Так безглуздо суперечні ці дві сторони мого існування. Немила я тому Порядкові, все, що не починаю. Порядок знівечить, а нащось уклав він мені мої прагнення. Це ж він, а не хто інший. Так, як би було два супротивники: 
один старається, другий розстроюе. $\mathrm{Hi}, \epsilon$ ще один Порядок, одна закономірність і... так безглуздо!

Наче ворог невидимий, всесильний і жорстокий переслідуе мене у всьому. Безсилий плач, такий тяжкий, що як ласки прошу: хоч би виплакатися, щоб стало легше. I воно тільки гірше, тільки тяжче. А тут ще «надежды юношей питают, отраду старцам подают». Двохденний роман очей, в якім пережито віки. I знов у безсилій безвиглядності хороню якусь мрію. Той самий погляд... і те саме нікуди. Хотіла б тільки я знати психологію цих людей. I чому на мою долю випадає тільки таке?

\section{II.50 p.}

Почуваю в собі велику силу, але зв’язуе її й давить щось ще більше.

Як у хаті, то треба кудись бігти, до інформації, до людей. Як прийду в ту сутолоку, - треба йти додому. Як сиджу - треба лягти. Як ляжу треба устати. Все роблю щось не те, що треба.

Підленька Івченко (йдеться про Людмилу Івченко. - Т.Ш.), пішла, випитала у Міщенків про другий афідавіт і пішла донесла.

Таке в мене виросло рішення, що ні до кого не звертатися, ні до Теклі, ні до Свдокії, а вже тим більше ні до галанів 3 жіночими організаціями, федераціями та івченками. Не напишу я й ні до кого, коли сідатиму на пароплав. Як узавтра буду мати щастя перейти на другий нумер, то там, що прийдеться, від християнської організації візьму. Ну, що ж, фрарма. Мені фрарми і треба. I нікого їх.

Учора Подоляк: «Зустріч МУРу, може там доповідь якась буде, а то так зустрітися, випити, повеселитися, душу відвести». I з ними ж так само. Друзів я не маю.

\section{II.50 p.}

В природі щось мене їсть, щось я їм - і так воно йде. А в суспільстві - увесь час мене їдять.

Я оце віднедавна почала думати, що викидання хліба на смітник не гріх. Однаково згние, переробиться в природі, як і в тілі німецької свині на гній. Гріх проти людей, що вклали свою працю в той хліб (нібито треба, щоб з'їло щось, бодай, німецька свиня). Що те сало? Однаково тобі не дадуть, як не маєш чим оплатити.

Ці юрби людей, що перекочуються через табір, такі сірі все, нецікаві. Одна маска на всіх. Одно тільки обличчя було серед них усіх. Видіння. Яка то може бути мені відповідність. I нема. У світі десь $е-\mathrm{i}$ то добре. Але для мене нема. Все це - cipi, сірі обличчя. I так жити? Це раз у житті і така ефемерида. Нічого. Навіть не присниться. Міраж якийсь. Чому я не маю того, що мені так потрібно? Обожнювання того, 
кого обожнюеш? А така пустеля, що нема сили жити. Нема сили. До людей, до роботи, до думок своїх, до читання.

\section{II.50 p.}

Багато чого зрозуміла я про расу. За ці дні. Можливо, вся людська доля залежить від потреб істоти поліпшити свою расу. Це так дубово сказано! Розшифрую. Безжалісно може, але ж треба вивести якісь кінці в моєму, незрозумілому самій мені, відчуженні від світу. Це відчуження все таки має джерелом біологічний підклад. Разом з непереможною волею до вибору $є$ дві частини одного я, навіть еротичного. Одне виконуе свої функції, чи готове, чи покірне виконувати, як і інші, воно живе своїм життям. Друге бунтівливе, жадливе, вибагливе - це сфера кохання, інстинкту вибору, творення нової раси. Воно стоїть завжди насторожі, - індивідуальний смак, критичність до того, що приходить, безкомпромісність і уподобання чогось одного, якоїсь деталі, частини в «ньому» чи в «ній». Так і повстае колізія закохання і відштовхування. Така людина в потокові перемішування европейської раси трапляеться раз на віки, або й не трапляється. I вибаглива воля того, чого потребує те еротичне «я», краще не мати ніякого, як не те, що хоче мати. I те невдоволення, безвихідність і неспожита енергія, що на сторожі її стоїть воля до вибору потрібного «моїй» расі, дає інший цвіт, цвіт творчості, після сум'ятиці духа. Потік людський на днях дав мені змогу побачити, що було б те, мені необхідне. Тільки побачити. I що було б, як би закраялася моя біографрія, якби таке прийшло в 16 років? Зовсім інша. Я б поліпшувала б мою расу і більш нічого?

Щось не так. Ще в початках дитячої свідомості я вже була «закраяна». Така ж непереможна воля була, але до ширяння духа. Може, якби навіть цей молодий чоловік був рівня мені віком, то був би чужий національною культурою, плаский... Ох, як багато ще треба до зовнішньої відповідності! Але раса його мене засліпила, як засліпила моя раса його. Ніколи нігде такого я не бачила, навіть наближеного. I як довго треба було мені жити, скільки людей надивитися, щоб нарешті здалека два рази побачити те, чого мені бракуе.

\section{III.50 р. приїхала до Нью-Йорку.}

А сьогодні 11-е липня і я ні слова не записала сюди! Навіщо, справді? Спостереження! Навіщо писати про ці ембріони? Про маревність ілюзій? Часом ілюзії зовсім заполоняють мене і я з брудом борюся з ними. Я, як Пеоні, часом до себе молюся: «Докіе, допоможи мені!» Докії я розповідаю, і з нею раджуся й роздумую.

А життя різнобарвними клаптями сунеться довкола й треба студій лише на запис. Як його все зрозуміти і якої дороги триматися, на якому сучку зачепитися? Від џього залежить, як мені бути і де подіти свій дух. 
Була творчість. Те припечатане, як негодяще. Нема сили опертися присудові. Струс із переїздом й новим стилем життя повинен відбитися в ньому, в підході до слова. Як же я розбита? I це нагнітання серця...

О, Докіе, допоможи мені!

Підготовка текстів, примітки кандидата фбілологічних наук ТЕТЯНИ ШВЕЦЬ (л. Хлильницький) 